\title{
Diversity, composition and phenology of araneid orb-weavers (Araneae, Araneidae) associated with riparian forests in southern Brazil
}

\author{
Everton N. L. Rodrigues' ${ }^{1}$, Milton de S. Mendonça Jr. ${ }^{2}$, Patrícia E. S. Rodrigues ${ }^{3}$ \& Ricardo Ott ${ }^{3}$
}

\author{
1. Laboratório de Diversidade e Sistemática de Arachnida, Programa de Pós-Graduação em Biologia, Universidade do Vale do Rio dos Sinos. Av. Unisinos, 950 , $93022-000$ \\ São Leopoldo, RS, Brazil. (enlrodrigues@unisinos.br) \\ 2. Departamento de Ecologia, Instituto de Biociências, Universidade Federal do Rio Grande do Sul. Av. Bento Gonçalves, 9500, Bloco IV, Prédio 43422, $91501-970$ Porto Alegre, RS, Brazil. \\ 3. Museu de Ciências Naturais, Fundação Zoobotânica do Rio Grande do Sul. Rua Dr. Salvador França, 1427, 90690-000 Porto Alegre, RS, Brazil.
}

\begin{abstract}
The Araneidae is a speciose family including web-spinning spiders that are very abundant in various terrestrial ecosystems. Several studies demonstrate that changes in vegetation surrounding rivers, streams and brooks affect the associated araneofauna. The aim of this research was to compare differences found in diversity (abundance and richness), composition and phenology of Araneidae spiders sampled in different habitats in four riparian forest catchments in southern Brazil. Samples were taken from riparian forests in four rivers of Rio Grande do Sul State: Piratini, Camaquã, Sinos and Maquiné rivers, each in a different hydrographic basin. Samples were taken twice seasonally on each basin during two years, sampling the araneofauna of the tree-shrub strata with beating tray. Six transects were employed on each basin, two per habitat: edge with grassland, forest interior and river edge. Araneids totalled 20 genera and 65 species. Comparing riparian forests significant differences are found. Spider abundance differed among riparian forests as well as species richness. Overall, Piratini river riparian forest had the higher abundance and richness for Araneidae; the lower values were in Sinos river forest. The stronger degradation and fragmentation of the riparian forests of Sinos river probably influenced the results, with human disturbance gradients associated negatively to web building. We present data on the diversity of these spiders, which were very abundant in the riparian forest interior and very rich in species in the grassland/riparian forest edge. Species composition also differs among the studied habitats (the above plus river/riparian forest edge). For the most abundant species the phenological pattern across the seasons was also analysed.
\end{abstract}

KEYWORDS. Spiders, habitats, Rio Grande do Sul, abundance, richness.

RESUMO. Diversidade, composição e fenologia de aranhas construtoras de teias (Araneae, Araneidae) associadas com matas ciliares no sul do Brasil. Araneidae é uma das famílias com maior número de espécies, incluindo aranhas construtoras de teias que são muito abundantes em diversos ecossistemas terrestres. Vários estudos demonstram que mudanças na vegetação circundante de rios, córregos e riachos pode afetar a araneofauna associada. O objetivo deste estudo foi avaliar aspectos sobre a diversidade (abundância e riqueza), composição e fenologia de aranhas Araneidae foram amostradas em diferentes habitats em quatro bacias de mata ciliar no sul do Brasil. Foram coletadas amostras de matas ciliares em quatro rios do Rio Grande do Sul, todos em diferentes bacias hidrográficas: nos rios Piratini, Camaquã, dos Sinos e Maquiné. As amostras foram realizadas duas vezes por estação em cada bacia, durante dois anos, a amostragem da araneofauna do estrato arbóreo-arbustivo foi realizada com guardachuva entomológico. Seis transecções foram empregadas em cada mata ciliar, dois por habitat: borda com campo, interior da floresta e borda do rio. Araneídeos totalizaram 20 gêneros e 65 espécies. Comparando-se as matas ciliares houve diferenças significativas. A abundância de aranhas diferiu entre as matas ciliares, bem como a riqueza de espécies. No geral, a mata ciliar do rio Piratini teve a maior abundância e riqueza para Araneidae; os menores valores foram no rio dos Sinos. A degradação e fragmentação da mata ciliar do rio dos Sinos, provavelmente influenciaram nos resultados, a partir da perturbação humana agindo de forma negativa nas aranhas da família Araneidae. Apresentamos dados sobre a diversidade destas aranhas, que foram muito abundantes no interior da mata ciliar e muito ricas em espécies na borda da mata com o campo. A composição de espécies também difere entre os habitats estudados. Para as espécies mais abundantes, o padrão fenológico em todas as estações do ano também foi analisado.

PALAVRAS-CHAVE. Aranhas, habitats, Rio Grande do Sul, abundância, riqueza.

Riparian forests are key elements in the landscape, being one of the few to remain, although quite altered, after agroecosystem "development" in many different environments. Riparian forests have an important function as corridors, potentially helping araneofauna dispersal between distant areas (RAIzER et al., 2005). Nevertheless, the spider fauna of this ecosystem remains poorly known, and few inventories and ecological researches have been developed there (for an exception, see RoDRigues \& Mendonça, 2012; Rodrigues et al., 2014).

Riparian forests are good corridors also because they are usually relatively narrow strips accompanying rivers (HARPER et al., 2007), and have been further reduced in their extension by human impacts. Thus, they are especially amenable to edge effects (MURCIA, 1995), and this could impact the spider fauna in different ways. For example, pioneer plants occupying edges, along with changed abiotic factors, could help augment insect herbivore activity on forest edges, which could positively impact spiders (WIRTH et al., 2008). On the other hand, plant structure (RodRIGUEs et al., 2014) and species richness (BALDISSERA et al., 2004) is essential to web building spiders and thus would generate an expectation for more abundant and richer spider assemblages on the forest interior.

The family Araneidae is the third in number of genera and species globally (World SidDer Catalog, 2015), including ecribellate, entelegyne, three-clawed spiders, having eight eyes in two rows. They are also notable for building orb webs (LEVI, 2002), which renders them easy to sample since they can be viewed and collected from webs, and puts them into a single functional hunting guild among spiders. They have a relatively large size and are colourful, 
being thus interesting ecologically and evolutionarily in terms of the value associated to these colours. They are quite well known taxonomically in the Holartic Region, and not surprisingly the Neotropical araneids are still largely undescribed and unknown.

Spiders in this family are generally among the most abundant and speciose of those sampled from the treeshrub plant strata in faunal inventories in southern Brazil, even from distinct ecosystems (INDRUSIAK \& KotZIAN, 1998; BALdissera et al., 2004; Rodrigues, 2005; Silva \& Araujo, 2005; Bonaldo et al., 2007; Podgaiski et al., 2007; BAldissera et al., 2008; Rodrigues et al., 2014). A species list was presented by INDRUSIAK \& Buss (2003) for the central region of Rio Grande do Sul State, and in the list of spiders species of Rio Grande do Sul State (BuCKUP et al., 2010) cite Araneidae as the family with the highest number of species to the State (210 species).

Araneidae is one of the few spider families of the Neotropical Region with a relatively well-known taxonomy. The available lists already paint a general picture of this fauna in the region, allowing comparisons not available for other spiders and even for other invertebrate groups. However, few species have ecological patterns known, such as occurrences and abundance in distinct habitats, phenology and so forth, Thus, the aim of this study was to evaluate aspects of diversity (abundance and richness), composition and phenology of Araneidae spiders species sampled from different habitats in four riparian forest catchments in southern Brazil. How environmental differences influence araneid spiders was also evaluated. Our expectations are that different araneid spider abundance and richness will be found on rivers to the north, within the Atlantic forest biome, given simply the latitudinal differences between this and the Pampa biome, to the south. Under the biological edge hypothesis, river edges and grassland/pasture edges are expected to differ in their effect on araneid spider diversity and different composition, given the distinct nature of these edges.

\section{MATERIAL AND METHODS}

Samples were taken from riparian forests in four rivers of Rio Grande do Sul State, Brazil, each in a different hydrographic basin.

In Piratini river sampling points were in the lower course, Arroio Grande municipality, southern part of the Coastal Plain macroregion (31 ${ }^{\circ} 54^{\prime} 06.47^{\prime \prime} \mathrm{S}$; $\left.52^{\circ} 39^{\prime} 08.29^{\prime \prime} \mathrm{W}\right)$. The sampled sector is approximately $14 \mathrm{~m}$ a.s.l. and is $39 \mathrm{~km}$ long in the fluvial valley, with a forest area of 4,000 ha, representing the largest continuous native riparian forest segment still extant in the southern half of the Coastal Plain.

In Camaquã river the left margin of the lower course was chosen, in Cristal municipality ( $31^{\circ} 01^{\prime} 01.7^{\prime}$ 'S; $\left.51^{\circ} 56^{\prime} 42.0^{\prime \prime} \mathrm{W}\right)$, centre-south part of the Coastal Plain. It is also approximately $14 \mathrm{~m}$ a.s.l. This area is well preserved, with continuous forest over the plains. This place is affected by natural intermittent flooding with few indications of anthropic disturbance.

The riparian forest of Sinos river is in Parobé municipality on the right river margin (2941'06.94'S; $\left.50^{\circ} 51^{\prime} 05.98^{\prime \prime} \mathrm{W}\right)$, between 6-10 $\mathrm{m}$ a.s.l. The forest is not continuous, with fragmentation along the river, but the chosen sampling sector includes a fraction of forest still in good condition. The forest on the right margin is taller, but with flooding plains, swamps and pastures nearby. On the other margin the forest was partially cut and the local people use the area for sunbathing and swimming (DANIEL, 1991).

The sampled sector of the riparian forest along Maquiné river is also reduced to a fragment, in Maquiné municipality (2940'47.99'S; 50¹1'20.03'W). With an approximate area of $622 \mathrm{~km}^{2}$, it is an enclave in the slopes of the highlands. This region is in the Atlantic Forest Biosphere Reserve as recognised by UNESCO, included in the Serra Geral Biological Reserve. It is considered of extreme importance to the conservation of the Brazilian Atlantic forest (CONSERVATION INTERNATIONAL Do BRASIL et al., 2000), because of its biodiversity and risk of anthropic change.

Field trips occurred during two years $(01$. August.2007-06.June.2009), with two sampling dates per season (spring, summer, autumn, winter) on each river, totalling eight samples per year, and 64 samples overall. Six transects (approximately $30 \mathrm{~m}$ each) were set up in each river basin. Therefore, there were two transects per habitat per area. Each transect was a straight line $4 \mathrm{~m}$ wide. Three habitats were contemplated: the forest-river edge (as close to the border between forest and river as possible, $\mathrm{RE}$ ); the forest interior (FI) and the forest-grassland edge (along the border between forest and adjacent vegetation, usually grassland but occasionally fallow land close to agriculture areas, GE). Spiders on the shrub-tree strata were collected with a beating tray $(70 \mathrm{~cm} \mathrm{x} 70 \mathrm{~cm})$ on each transect during $45 \mathrm{~min}$. Overall, 24 transects were sampled per field trip across all rivers; $288 \mathrm{~h}$ of sampling were completed for the whole period.

Spiders were identified in the Laboratório de Aracnologia and deposited in the spider collection of Museu de Ciências Naturais of Fundação Zoobotânica do Rio Grande do Sul, Porto Alegre, Brazil (curator: R. Ott).

Analytical species richness estimator Jackknife1 was calculated to verify sampling sufficiency, as suggested by Тоті et al. (2000). For this we used EstimateS 8.0 (Colwell, 2005) with 500 randomisations. To test for conjunct differences in sample species richness and abundance among riparian forests (rivers) and habitats (edges and forest) a two-way MANOVA (with Pillai's Trace statistic) was employed (calculated with SPSS ${ }^{\circledR} 13.0$ ). To illustrate spider species composition comparisons two ordinations were plotted (Non-metric MultiDimensional Scaling - nMDS), one using a qualitative similarity index (Simpson) and another a quantitative one (Bray-Curtis). To test for statistical differences among spider assemblage 
composition for the above similarity indexes, we applied two one-way ANOSIM (Analysis of Similarities) with Bonferroni correction, one for each factor (habitat and river) (Clarke \& Warwick, 1994). Phenograms were built for species with more than 10 individuals sampled, except for Eustala (a genus currently being revised, Maria Rita Poeta, MCTP, pers. comm.), to illustrate patterns of distribution in time across the two years of sampling.

\section{RESULTS AND DISCUSSION}

Of a total 42,057 spiders sampled (adults and juveniles) in this riparian forest for Rio Grande do Sul State, 5,020 belonged to Araneidae (533 adults and 4,489 juveniles), the third most abundant family. More females (360) than males (173, sex ratio 1:0.48) were captured.

Twenty genera and 65 species were found (Tab. I), among rare species 25 were singletons (more than 38\%) and seven were doubletons $(10.8 \%)$. Similar work with the same method varied in this percentage of rare species for the family, Silva \& AraúJo (2005) found high values (82\% singletons), but INDRUSIAK \& BUSS (1998) found low (8\%); other work remained between 30-40\% (RoDRIGUES, 2005; Bonaldo et al., 2007; Podgaiski et al., 2007). CodDington et al. (2009), comparing several inventories, estimated for spiders an average percentage of $37.2 \%$ singletons, very close to what was found here.

The species richness estimator (Jackknife1) returned $44.1( \pm 3.32,95 \% \mathrm{CI})$ species for Piratini river (70.2\% of the spider fauna would have been sampled for that environment); $41( \pm 4.11)$ species for Camaquã river $(63 \%$ sampled $) ; 36.1( \pm 4.08)$ species for Sinos river $\left(63.7 \%\right.$ sampled) and $39.2\left({ }^{ \pm 3.21}\right)$ species for Maquiné river $(71.3 \%)$ sampled. Even after two whole years of sampling, a high number of species (in RS, the only one below the work by PoDGaiski et al., 2007) and with new records for

Tab. I. Spider species list for the Araneidae, sampled during two years (01.August.2007-06.July.2009) from three habitats in riparian forests of southern Brazil (GE, grassland edge; FI, forest interior; RE, river edge).

\begin{tabular}{|c|c|c|c|c|c|c|c|c|c|c|c|c|c|c|}
\hline \multirow{3}{*}{ Species } & \multicolumn{12}{|c|}{ Riparian forests - Rivers } & \multirow{3}{*}{ Total } & \multirow{3}{*}{$1 \%$} \\
\hline & \multicolumn{3}{|c|}{ Piratini } & \multicolumn{3}{|c|}{ Camaquã } & \multicolumn{3}{|c|}{ Sinos } & \multicolumn{3}{|c|}{ Maquiné } & & \\
\hline & GE & FI & RE & GE & FI & $\mathrm{RE}$ & GE & FI & RE & GE & FI & RE & & \\
\hline Acasesia graciosa Lise \& Braul, 1995 & 0 & 0 & 0 & 0 & 1 & 0 & 0 & 0 & 0 & 2 & 0 & 0 & 3 & 0,56 \\
\hline Alpaida alticeps (Keys., 1880) & 0 & 0 & 0 & 0 & 0 & 0 & 0 & 0 & 0 & 2 & 2 & 0 & 4 & 0,75 \\
\hline Alpaida citrina (Keys., 1892) & 0 & 0 & 0 & 0 & 0 & 0 & 0 & 0 & 0 & 10 & 0 & 0 & 10 & 1,88 \\
\hline Alpaida erica Levi, 1988 & 1 & 0 & 0 & 0 & 0 & 0 & 0 & 0 & 0 & 0 & 0 & 0 & 1 & 0,19 \\
\hline Alpaida grayi (Blackwall, 1863) & 0 & 0 & 0 & 0 & 0 & 0 & 0 & 0 & 0 & 5 & 0 & 0 & 5 & 0,94 \\
\hline Alpaida lomba Levi, 1988 & 1 & 0 & 0 & 0 & 0 & 0 & 0 & 0 & 0 & 0 & 0 & 0 & 1 & 0,19 \\
\hline Alpaida nonoai Levi, 1988 & 0 & 0 & 0 & 2 & 0 & 0 & 0 & 0 & 0 & 0 & 0 & 0 & 2 & 0,38 \\
\hline Alpaida octolobata Levi, 1988 & 0 & 4 & 0 & 0 & 12 & 0 & 0 & 0 & 0 & 0 & 0 & 0 & 16 & 3 \\
\hline Alpaida pedro Levi, 1988 & 0 & 0 & 0 & 0 & 1 & 0 & 0 & 0 & 0 & 0 & 2 & 0 & 3 & 0,56 \\
\hline Alpaida truncata (Keys., 1865) & 0 & 0 & 0 & 0 & 0 & 0 & 0 & 1 & 0 & 0 & 0 & 0 & 1 & 0,19 \\
\hline Araneus omnicolor (Keys., 1893) & 0 & 2 & 1 & 0 & 1 & 1 & 0 & 2 & 0 & 0 & 5 & 1 & 13 & 2,44 \\
\hline Araneus unanimus (Keys., 1880) & 4 & 0 & 0 & 1 & 1 & 2 & 0 & 0 & 0 & 0 & 0 & 0 & 8 & 1,5 \\
\hline Araneus uniformis (Keys., 1880) & 2 & 0 & 0 & 0 & 0 & 0 & 0 & 0 & 0 & 0 & 0 & 0 & 2 & 0,38 \\
\hline Araneus venatrix (C.L. Koch, 1839) & 0 & 1 & 0 & 0 & 0 & 0 & 0 & 0 & 0 & 1 & 1 & 1 & 4 & 0,75 \\
\hline Araneus vincibilis (Keys., 1893) & 0 & 3 & 0 & 0 & 0 & 0 & 1 & 2 & 0 & 0 & 0 & 0 & 6 & 1,13 \\
\hline Bertrana rufostriata Simon, 1893 & 1 & 0 & 0 & 0 & 0 & 0 & 5 & 0 & 0 & 1 & 0 & 0 & 7 & 1,31 \\
\hline Cyclosa camargoi Levi, 1999 & 0 & 0 & 0 & 1 & 0 & 0 & 0 & 0 & 0 & 0 & 0 & 0 & 1 & 0,19 \\
\hline Cyclosa diversa (O.P.-Cambridge, 1894) & 0 & 0 & 0 & 0 & 0 & 0 & 0 & 0 & 1 & 0 & 0 & 0 & 1 & 0,19 \\
\hline Cyclosa fililineata Hingston, 1932 & 0 & 2 & 0 & 0 & 1 & 0 & 0 & 7 & 0 & 0 & 0 & 0 & 10 & 1,88 \\
\hline Cyclosa inca Levi, 1999 & 0 & 0 & 0 & 0 & 0 & 2 & 0 & 0 & 0 & 0 & 0 & 0 & 2 & 0,38 \\
\hline Cyclosa machadinho Levi, 1999 & 1 & 0 & 0 & 0 & 1 & 0 & 1 & 5 & 1 & 0 & 6 & 1 & 16 & 3 \\
\hline Cyclosa morretes Levi, 1999 & 1 & 0 & 0 & 0 & 1 & 0 & 0 & 0 & 0 & 0 & 0 & 0 & 2 & 0,38 \\
\hline Eustala photographica Mello-Leitão, 1944 & 1 & 0 & 10 & 0 & 0 & 3 & 0 & 0 & 0 & 0 & 0 & 0 & 14 & 2,63 \\
\hline Eustala saga (Keys., 1893) & 0 & 0 & 0 & 0 & 0 & 0 & 0 & 0 & 0 & 1 & 0 & 0 & 1 & 0,19 \\
\hline Eustala sanguinosa (Keys., 1893) & 0 & 0 & 2 & 1 & 0 & 0 & 0 & 0 & 0 & 0 & 0 & 0 & 3 & 0,56 \\
\hline Eustala sp.1 & 0 & 0 & 0 & 0 & 0 & 0 & 0 & 0 & 0 & 1 & 0 & 0 & 1 & 0,19 \\
\hline Eustala sp.2 & 4 & 0 & 0 & 0 & 0 & 0 & 0 & 0 & 0 & 0 & 0 & 0 & 4 & 0,75 \\
\hline Eustala sp. 3 & 0 & 0 & 0 & 0 & 1 & 0 & 0 & 0 & 0 & 0 & 0 & 0 & 1 & 0,19 \\
\hline Eustala sp.4 & 4 & 0 & 3 & 0 & 0 & 0 & 0 & 0 & 0 & 1 & 0 & 0 & 8 & 1,5 \\
\hline Eustala sp.5 & 0 & 0 & 0 & 0 & 0 & 1 & 0 & 0 & 0 & 0 & 0 & 0 & 1 & 0,19 \\
\hline Eustala sp.6 & 0 & 0 & 0 & 0 & 0 & 0 & 1 & 0 & 0 & 0 & 0 & 0 & 1 & 0,19 \\
\hline Eustala taquara (Keys., 1892) & 5 & 0 & 0 & 12 & 0 & 4 & 9 & 0 & 8 & 3 & 0 & 0 & 41 & 7,69 \\
\hline Gasteracantha cancriformis (L., 1767) & 2 & 1 & 2 & 0 & 0 & 0 & 0 & 0 & 1 & 3 & 0 & 0 & 9 & 1,69 \\
\hline Hypognatha viamao Levi, 1996 & 1 & 1 & 0 & 0 & 0 & 0 & 0 & 0 & 0 & 1 & 1 & 0 & 4 & 0,75 \\
\hline Larinia montecarlo (Levi, 1998) & 0 & 0 & 0 & 1 & 0 & 0 & 0 & 0 & 1 & 0 & 0 & 0 & 2 & 0,38 \\
\hline Mangora fundo Levi, 2007 & 3 & 0 & 1 & 0 & 0 & 0 & 0 & 0 & 0 & 1 & 0 & 0 & 5 & 0,94 \\
\hline Mangora lactea Mello-Leitão, 1944 & 2 & 1 & 0 & 0 & 0 & 0 & 0 & 0 & 0 & 0 & 0 & 0 & 3 & 0,56 \\
\hline Mangora melanocephala (Taczanowski, 1878) & 0 & 0 & 0 & 0 & 0 & 0 & 3 & 0 & 1 & 0 & 0 & 0 & 4 & 0,75 \\
\hline Mangora missa Levi, 2007 & 0 & 0 & 0 & 0 & 0 & 0 & 0 & 0 & 0 & 0 & 1 & 0 & 1 & 0,19 \\
\hline Mangora piratini Rodrigues \& Mendonça, 2011 & 0 & 1 & 0 & 0 & 0 & 0 & 0 & 0 & 0 & 0 & 0 & 0 & 1 & 0,19 \\
\hline Mangora strenua (Keys., 1893) & 8 & 68 & 11 & 1 & 21 & 8 & 0 & 9 & 1 & 1 & 3 & 3 & 134 & 25,1 \\
\hline Mecynogea bigibba Simon, 1903 & 0 & 0 & 0 & 0 & 0 & 0 & 1 & 0 & 0 & 0 & 0 & 0 & 1 & 0,19 \\
\hline
\end{tabular}


Tab. I. Cont

\begin{tabular}{|c|c|c|c|c|c|c|c|c|c|c|c|c|c|c|}
\hline \multirow{3}{*}{ Species } & \multicolumn{12}{|c|}{ Riparian forests - Rivers } & \multirow{3}{*}{ Total } & \multirow{3}{*}{$11 \%$} \\
\hline & \multicolumn{3}{|c|}{ Piratini } & \multicolumn{3}{|c|}{ Camaquã } & \multicolumn{3}{|c|}{ Sinos } & \multicolumn{3}{|c|}{ Maquiné } & & \\
\hline & GE & FI & $\mathrm{RE}$ & GE & FI & RE & GE & FI & RE & GE & FI & $\mathrm{RE}$ & & \\
\hline Metazygia floresta Levi, 1995 & 0 & 0 & 0 & 0 & 0 & 0 & 1 & 0 & 0 & 0 & 0 & 0 & 1 & 0,19 \\
\hline Metazygia genialis (Keys., 1892) & 0 & 0 & 0 & 1 & 0 & 0 & 0 & 0 & 0 & 0 & 0 & 0 & 1 & 0,19 \\
\hline Metazygia lagiana Levi, 1995 & 0 & 0 & 0 & 0 & 0 & 0 & 0 & 0 & 1 & 0 & 0 & 0 & 1 & 0,19 \\
\hline Metepeira compsa (Chamberlin, 1916) & 0 & 0 & 0 & 0 & 0 & 0 & 1 & 0 & 0 & 0 & 0 & 0 & 1 & 0,19 \\
\hline Metepeira glomerabilis (Keys., 1892) & 0 & 0 & 0 & 0 & 0 & 0 & 1 & 0 & 0 & 0 & 0 & 0 & 1 & 0,19 \\
\hline Micrathena furva (Keys., 1892) & 0 & 1 & 0 & 0 & 0 & 0 & 0 & 0 & 0 & 0 & 0 & 0 & 1 & 0,19 \\
\hline Micrathena guanabara Levi, 1985 & 0 & 2 & 0 & 0 & 2 & 0 & 0 & 6 & 0 & 0 & 2 & 1 & 13 & 2,44 \\
\hline Micrathena jundiai Levi, 1985 & 0 & 0 & 0 & 0 & 0 & 0 & 0 & 0 & 0 & 2 & 0 & 0 & 2 & 0,38 \\
\hline Micrathena lata Chickering, 1960 & 1 & 0 & 0 & 0 & 0 & 0 & 0 & 0 & 0 & 0 & 0 & 0 & 1 & 0,19 \\
\hline Micrathena nigrichelis Strand, 1908 & 0 & 0 & 0 & 0 & 0 & 0 & 0 & 0 & 0 & 0 & 1 & 0 & 1 & 0,19 \\
\hline Micrathena spitzi Mello-Leitão, 1932 & 3 & 24 & 3 & 1 & 3 & 6 & 0 & 0 & 0 & 0 & 0 & 1 & 41 & 7,69 \\
\hline Ocrepeira fiebrigi (Dahl, 1906) & 0 & 0 & 0 & 0 & 0 & 0 & 1 & 0 & 0 & 0 & 0 & 0 & 1 & 0,19 \\
\hline Ocrepeira galianoae Levi, 1993 & 4 & 2 & 2 & 0 & 0 & 0 & 0 & 0 & 0 & 0 & 0 & 0 & 8 & 1,5 \\
\hline Ocrepeira gnomo (Mello-Leitão, 1943) & 2 & 0 & 1 & 0 & 1 & 1 & 0 & 0 & 0 & 0 & 1 & 0 & 6 & 1,13 \\
\hline Ocrepeira malleri Levi, 1993 & 0 & 0 & 0 & 0 & 0 & 1 & 0 & 0 & 0 & 0 & 0 & 0 & 1 & 0,19 \\
\hline Parawixia audax (Blackwall, 1863) & 0 & 0 & 0 & 0 & 1 & 0 & 0 & 0 & 1 & 2 & 0 & 3 & 7 & 1,31 \\
\hline Parawixia velutina (Taczanowski, 1878) & 0 & 0 & 0 & 0 & 0 & 0 & 0 & 1 & 0 & 0 & 0 & 0 & 1 & 0,19 \\
\hline Scoloderus cordatus (Taczanowski, 1879) & 14 & 4 & 1 & 16 & 4 & 8 & 1 & 14 & 1 & 0 & 2 & 4 & 69 & 12,9 \\
\hline Testudinaria lemniscata (Simon, 1893) & 0 & 0 & 0 & 0 & 0 & 0 & 0 & 0 & 0 & 0 & 10 & 0 & 10 & 1,88 \\
\hline Testudinaria quadripunctata Taczanowski, 1879 & 0 & 0 & 0 & 0 & 0 & 0 & 0 & 0 & 0 & 1 & 0 & 0 & 1 & 0,19 \\
\hline Verrucosa meridionalis (Keys., 1892) & 0 & 0 & 0 & 0 & 0 & 0 & 0 & 0 & 0 & 0 & 3 & 0 & 3 & 0,56 \\
\hline Verrucosa undecimvariolata (O.P.-Cambridge, 1889) & 3 & 0 & 0 & 0 & 0 & 0 & 0 & 0 & 0 & 0 & 0 & 0 & 3 & 0,56 \\
\hline Wagneriana taim Levi, 1991 & 0 & 0 & 0 & 0 & 0 & 2 & 0 & 0 & 0 & 0 & 0 & 0 & 2 & 0,38 \\
\hline Total individuals & 68 & 117 & 37 & 37 & 52 & 39 & 26 & 47 & 17 & 38 & 40 & 15 & & \\
\hline Richness & 22 & 15 & 11 & 10 & 15 & 12 & 12 & 9 & 10 & 17 & 14 & 8 & 533 & 100 \\
\hline
\end{tabular}

southern Brazil, in all rivers estimates were below 75\% of the Araneidae fauna being sampled.

About differences in the araneid spider abundance and richness found on rivers, comparing riparian forests (MANOVA) for average, significant differences are found (Pillai's Trace, value $=1.16 ; \mathrm{F}=5.53 ; \mathrm{p}=0.001$ ). Spider abundance differed among riparian forests (MANOVA, F $=18.976 ; \mathrm{p}<0.0001$, Fig. 1$)$ as well as species richness $(\mathrm{F}$ $=9.93 ; p=0.001$, Fig. 2). Overall, Piratini river riparian forest had the higher total abundance $\left(\mathrm{N}=1900, \mathrm{~N}_{\text {adults }}=\right.$ 222) and richness $(\mathrm{S}=31)$ for Araneidae; the lower values were in Sinos river forest $\left(\mathrm{N}=749, \mathrm{~N}_{\text {adults }}=90 ; \mathrm{S}=23\right)$. The stronger degradation and fragmentation of the riparian forests in Sinos river probably influenced the results, with human disturbance gradients associated negatively to web building. There are previous demonstrations that anthropic changes to the environment influence the spider fauna (LAESER et al., 2005; BENATi et al., 2005).

Six species were common among all riparian forests: Araneus omnicolor (Keyserling, 1893), Cyclosa machadinho Levi, 1999, Eustala taquara (Keyserling, 1892), Mangora strenua (Keyserling, 1893), Micrathena guanabara Levi, 1985 and Scoloderus cordatus (Taczanowski, 1879). Maquiné river forests had the higher number of exclusive species (11) (Tab. I). Among the Araneidae recorded for riparian forests in southern Brazil, 59 were determined to the species level (91\%). Among those, more than $60 \%$ were shared with two spider fauna lists for Rio Grande do Sul State: INDRUSIAK \& Buss (1998), in Santa Maria, in the centre of the State, where one of the sites studied was a riparian forest as well, and with
Rodrigues (2005) in Capão do Leão, south of the State, studying a restinga (sandy soil sclerophyllous) forest. A comparison with BONALDO et al. (2007), studying various environments, among them five sites in riparian forests, yields 53\% similarity for the Araneidae fauna.

Comparisons with different ecosystems reveal a distinct Araneidae fauna, PoDGAISKI et al. (2007) studied the araneofauna for the northwestern forests of RS, with high species richness, but recording only $38,7 \%$ of shared araneid species with ours. The same is valid for BALDISSERA et al. (2008) considering mixed broad-leaved/Araucaria forests and Pinus plantations, sampling manually from the tree-shrub layer, attaining 37\% similarity only with our data.

Comparing habitats (MANOVA), significant differences are again found (Pillai's Trace, value $=0.90$; $\mathrm{F}=4.86 ; \mathrm{p}=0.005)$. Among habitats, forest interior had the highest abundance $(\mathrm{N}=1,922)$, followed by grassland edge $(1,843)$ and river edge $(1,257)$ spider abundance differed among habitats (MANOVA, $\mathrm{F}=9.90 ; \mathrm{p}=0.001$, Fig. 3); the same pattern holds for adult spiders only (FI $=256 ; \mathrm{GE}=169 ; \mathrm{RE}=108)$. Species richness was higher in the grassland edge $(\mathrm{GE}$, richness mean $=10.63 ; \mathrm{S}=$ 45 ), followed by forest interior (FI, richness mean $=9.13$; $\mathrm{S}=30)$ and river edge $(\mathrm{RE}$, richness mean $=7.13 ; \mathrm{S}=$ $25)$; species richness differed among habitats $(\mathrm{F}=7.62$; $\mathrm{p}=0.007$, Fig. 4). RodRIGUES (2005) recorded a similar pattern, with higher Araneidae abundance within the forest but higher species richness in the ecotone, here equivalent to the edge. BALDISSERA et al. (2004) recorded higher Araneidae abundance in the forest interior, with richness not differing from the edge. The same author considers that orb 

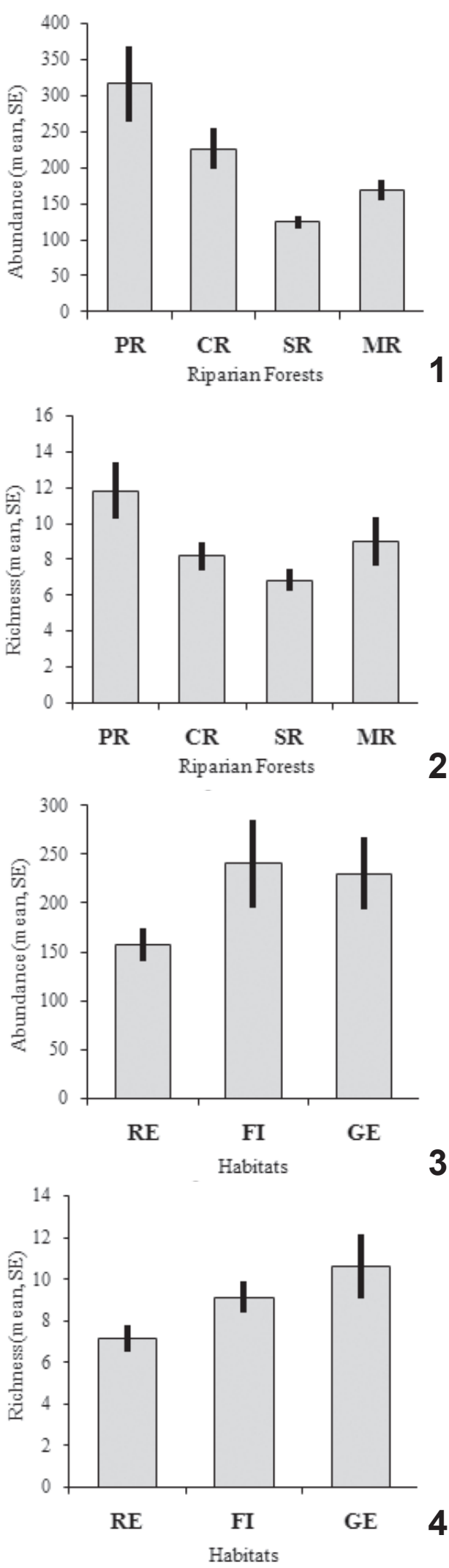

Figs 1-4. Abundance and species richness for habitats and riparian forests of southern Brazil: 1, abundance in riparian forests; 2 , species richness in riparian forests; 3 , abundance in habitats; 4 , species richness in habitats (habitats: GE, grassland edge; FI, forest interior; RE, river edge; riparian forests: PR, Piratini river; CR, Camaquã river; SR, Sinos river; MR, Maquiné river). weaving spiders can be strongly influenced by the edge effect, especially given microclimate changes. A higher abundance in the forest interior can be a result of a lower stress in terms of lower wind speeds and light intensity, however the higher richness in the edge requires an alternative explanation (see RODRIGUES et al., 2014).

Web building sites requires not only specific microclimates, but also space (FoELIX, 1996), which in the grassland edge appears nearly unlimited; besides, this habitat had a high number of exclusive species $(\mathrm{S}=23)$ but a high number of species shared with the forest interior. A gradient in abiotic conditions could be responsible for this, with certain species being able to withstand the edge and occur in both habitats, but some only finding appropriate conditions in the proper edge.

The forest interior registered 13 exclusive species, river edge had five and ten species were common to all habitats. Most of these species were represented by a few individuals (singletons or doubletons), preventing a proper assessment of environment preference.

Faunal similarity, compared among habitats in the riparian forests, recorded significant differences for both indexes used: qualitative (ANOSIM: Simpson, R = $0.222 ; p=0.040$ ) and quantitative (Bray-Curtis, $R=0.274$; $p=0.033$ ). The forest interior is the most distinctive in species composition, differing from edges both for the qualitative $(p=0.02)$ and the quantitative $(p=0.03)$ index (Figs 5,6). That is, even with the grassland edge richer in species, araneid species composition between the edges is similar, but the forest interiors are distinct. It appears that environmental factors related to the edge itself are more important than those related to the nearby habitat or matrix (grassland or river).

The temporal distribution of the Araneidae along two years shows a clear summer peak in numbers, valid for both sexes. Males appeared more homogeneously across time, but females are unequal in their time distribution (Fig. 7). Species richness was higher in the first year during spring ( $\mathrm{S}=21$ ), as found by PODGAISKI et al. (2007) for Araneidae; however in the second year summer had the higher richness $(S=19)$. Winter had the lowest richness for both years ( $\mathrm{S}=6$ and 7, respectively, Fig. 8).

For the most abundant araneid species the phenological pattern across the seasons was also analysed. Mangora was the predominant genus in riparian forests, both in abundance and richness. The most abundant species was $M$. strenua $(\mathrm{N}=134 ; 25 \%$ of all sampled adults), recorded in many samples with both males and females, peaking during summer and autumn both in the first and second years; it had a low frequency for winter and spring (Fig. 9). Most individuals were found in the forest interior $(75 \%)$.

Scoloderus cordatus was sampled from all riparian forests and was the second most abundant Araneidae $(\mathrm{N}=$ $69 ; 12.9 \%)$. Females of this species peaked in spring and summer, although males were registered more commonly in spring (Fig. 10). This species is among the most abundant in 


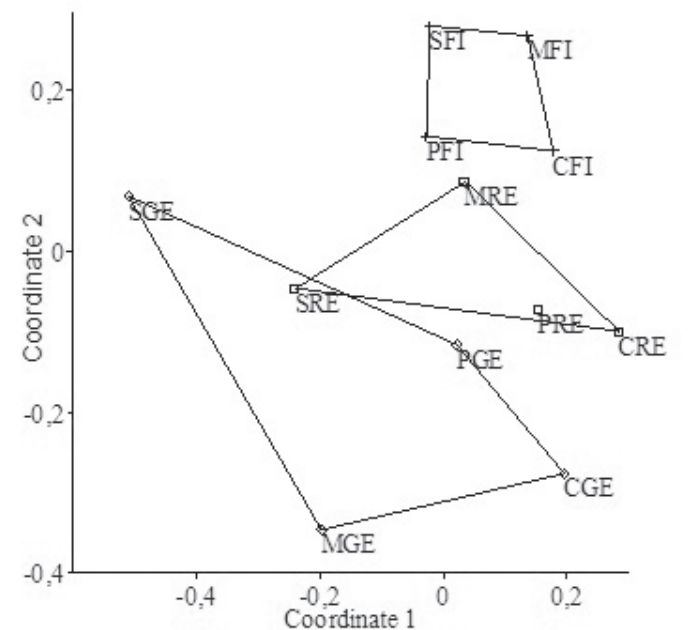

5

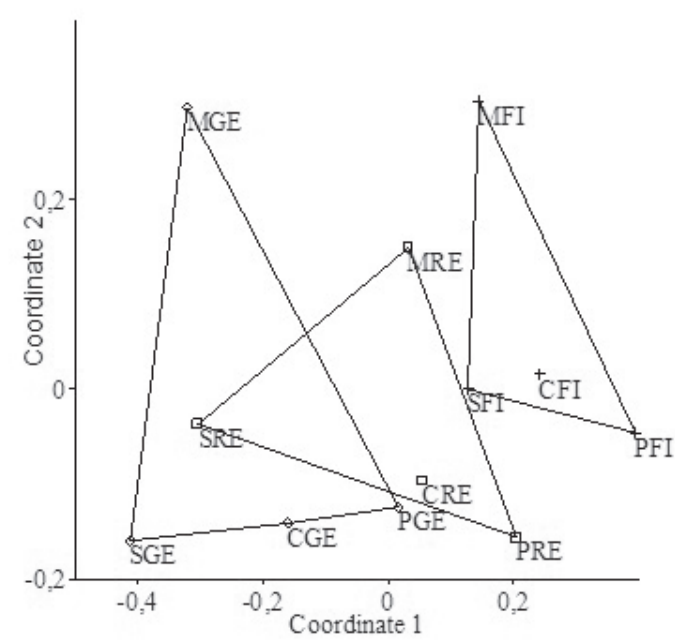

Figs 5, 6. Ordination of spider faunal composition for three habitats in the riparian forests of southern Brazil. Non-Metric MultiDimensional Scaling (nMDS, using qualitative and quantitative similarity indexes): 5, Simpson index, Stress $=0,231 ; 6$, Bray-Curtis index, Stress $=0,163$ (P, Piratini river; C, Camaquã river; S, Sinos river; M, Maquiné river; $\mathrm{GE}$, grassland edge; FI, forest interior; RE, river edge).

other inventories as well (PoDGAISKI et al., 2007; BALDISSERA et al., 2008), being known from grass and scrub vegetation (LeVI, 1995). This holds true here as well, since most (45\%) of these spiders were found in the grassland edge.

Two Micrathena species were abundant: $M$. spitzi $(\mathrm{N}=41 ; 7.69 \%)$ and $M$. guanabara $(\mathrm{N}=13 ; 2.44 \%)$. In the first, both sexes occur only during summer and autumn (Fig. 11), being represented mostly in the forest interior (66\%), but not recorded in Sinos riparian forests. It has been sampled from restinga shurbland and seasonal deciduous forest in RS State (RodRIGUES, 2005; PODGAISKI et al., 2007). Micratena guanabara was recorded from all rivers also with a preference for forest interior (92\%); it was not recorded for either autumn or winter (Fig. 12).

We found nine Alpaida species, three being singletons. A. octolobata $(\mathrm{N}=16 ; 3 \%)$ and $A$. citrina $(\mathrm{N}=$ $10 ; 1.88 \%$ ) were the most abundant. Alpaida octolobata had its higher peak in numbers in the third sample during spring, however, only during summer and autumn both sexes were recorded together (Fig. 13). This species was found only in the more southern rivers, Piratini and Camaquã and only for forest interior. Alpaida citrina had males and females only for the second sample during winter (Fig. 14); this species was exclusive for Maquiné river in the grassland edge.

Seven Cyclosa species occurred, the most abundant C. machadinho $(\mathrm{N}=16 ; 3 \%)$, recorded in all riparian forests, and then C. fililineata; both were found mainly in the forest interior. Cyclosa machadinho had males and females only for the fifth sample, during summer (Fig. 15); but females peaked at various times along the samples. Cyclosa filitineata had two summer peaks, with male and females together only for the summer of the first sampling year (Fig. 16). PodGaiski et al. (2007) registered both species for the seasonal deciduous forest of high Uruguai river in RS and Levi (1999) cites C. fililineata as occurring in gallery forests.

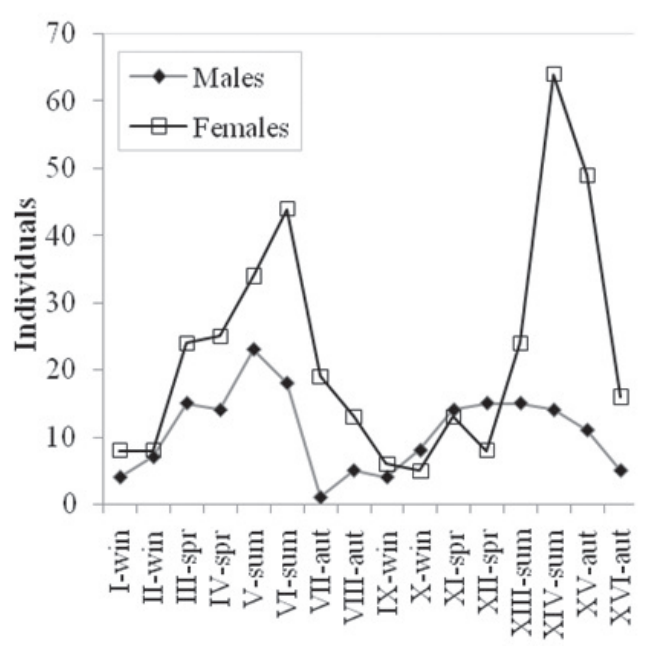

Samples

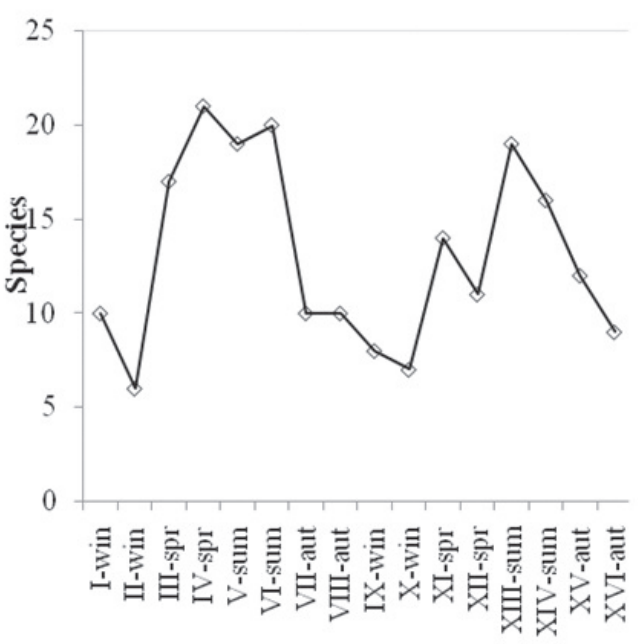

Samples

Figs 7, 8. Spider distribution in time for Araneidae (adults) along two years of sampling (01.August.2007-06.July.2009) for three habitats in the riparian forests of southern Brazil: 7, Male and female abundance; 8, Species richness (win, winter; spr, spring; sum, summer; aut, autumn). 


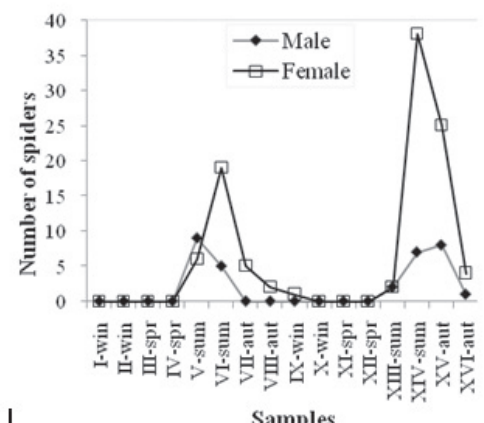

9
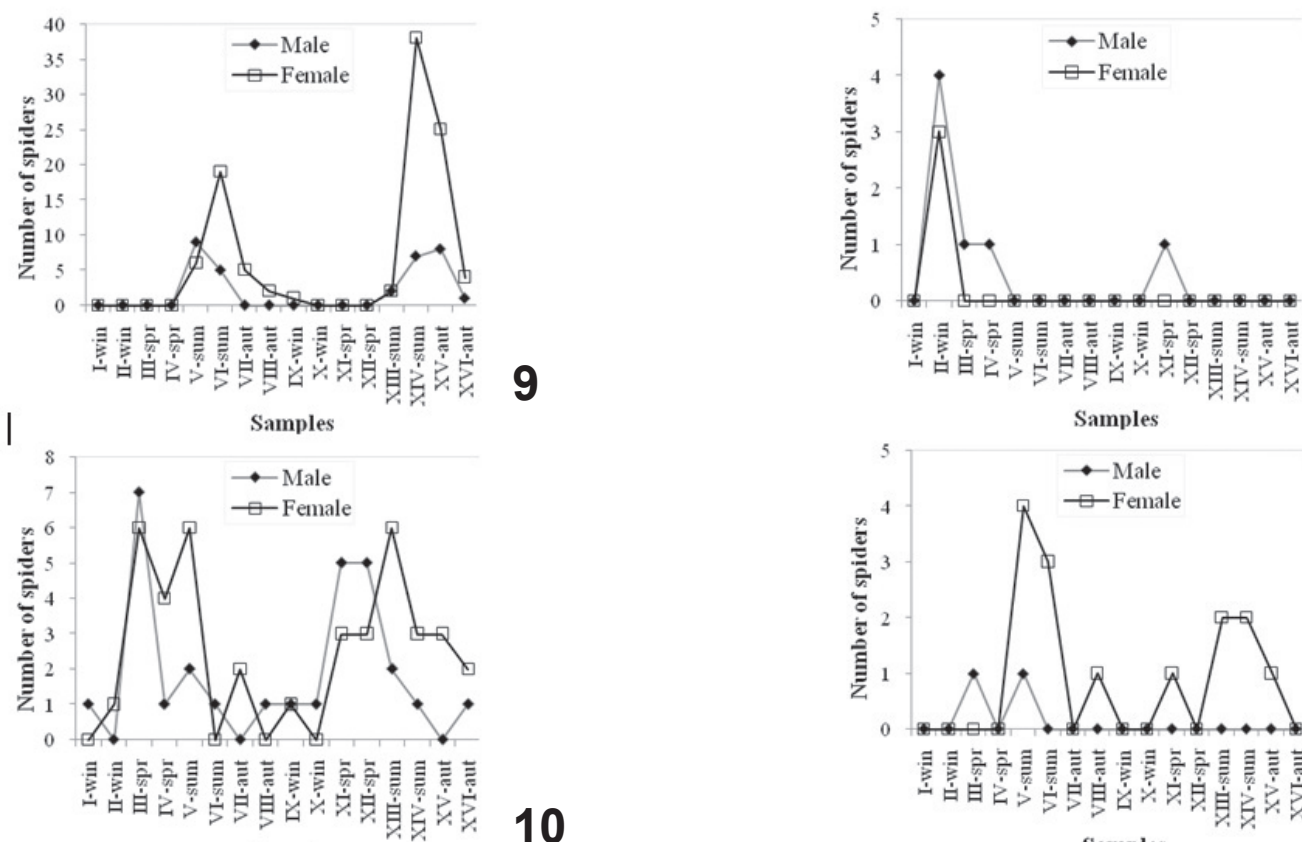

Samples

10

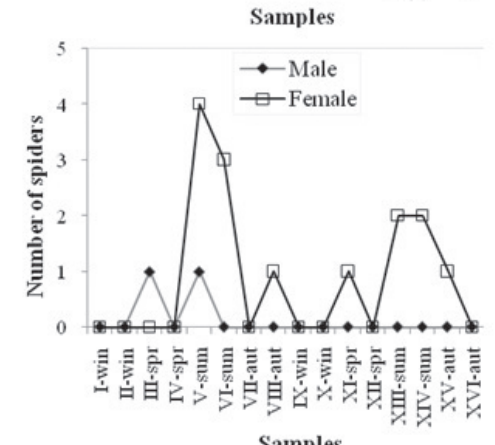

14

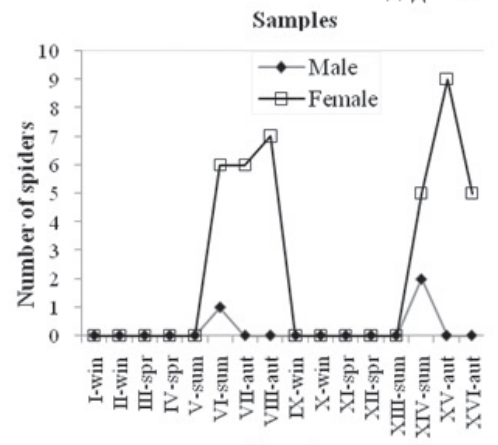

11

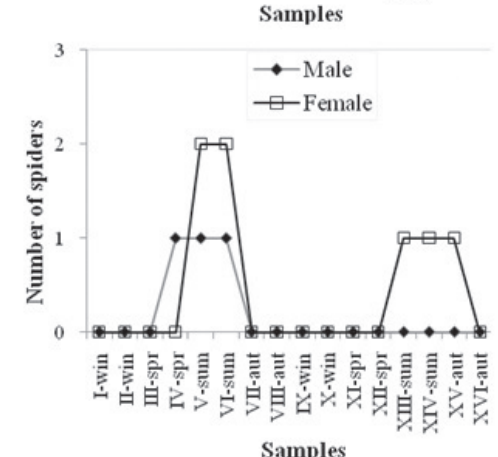

15

Samples

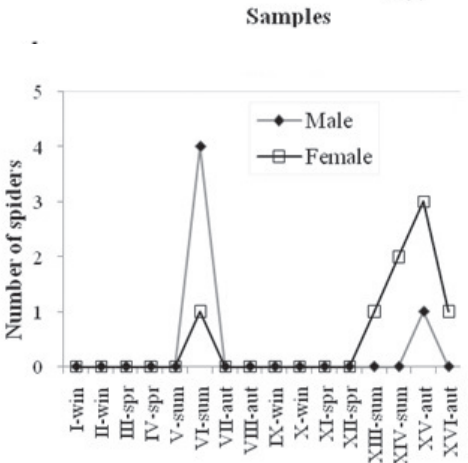

16

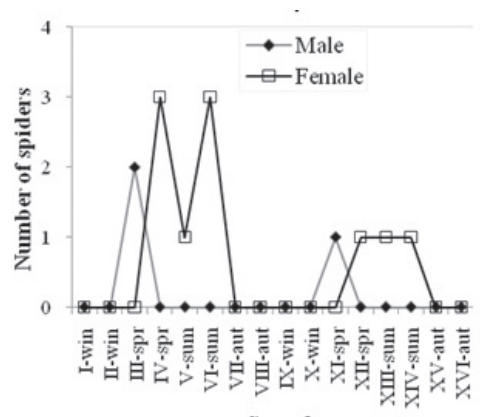

12
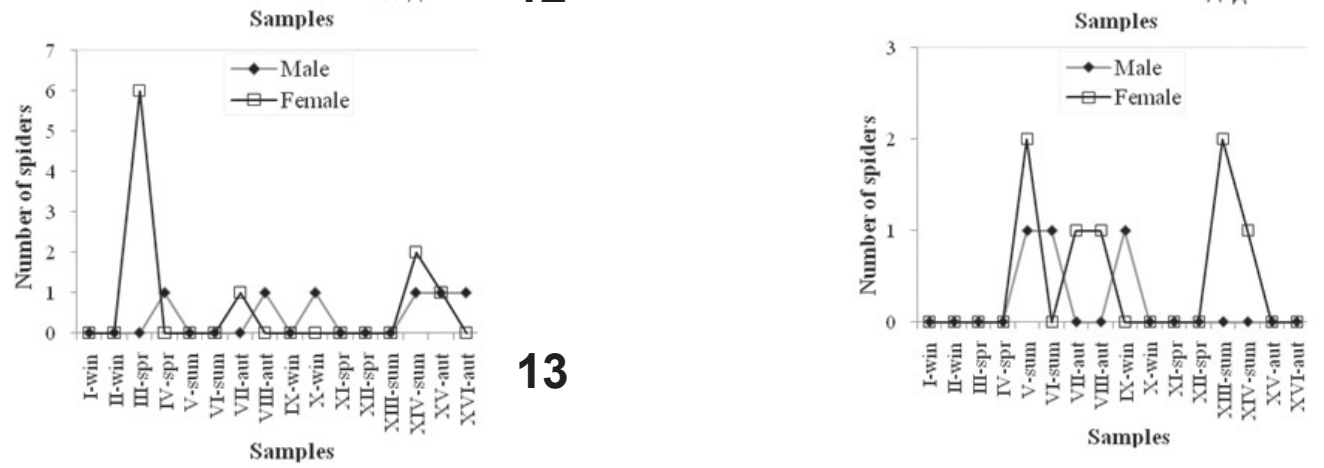

Figs 9-18. Temporal profile for the most abundant species of Araneidae ( $\mathrm{N}>10$ individuals, except Eustala) in riparian forests of southern Brazil: 9, Mangora strenua; 10, Scoloderus cordatus; 11, Micrathena spitzi; 12, Micrathena guanabara; 13, Alpaida octolobata; 14, Alpaida citrina; 15, Cyclosa machadinho; 16, Cyclosa fililineata; 17, Araneus ominicolor; 18, Testudinaria lemniscata. 
Araneus was represented by five species, with $A$. omnicolor the most abundant $(\mathrm{N}=13 ; 2,44 \%)$ and the only in the genus to be found from all riparian forests, with individuals present only during summer and autumn (Fig. 17), and mostly in the forest interior (77\%). Araneus omnicolor according to LeVI (1991) is to be found in humid forests; it has been recorded in various studies from different ecosystems in RS State (INDRUSIAK \& Buss, 2003; Rodrigues, 2005; SiLVA \& AraúJo, 2005; PodGaiskI et al., 2007).

The two species registered for Testudinaria were sampled exclusively from Maquiné river, $T$. lemniscata $(\mathrm{N}=10 ; 1.88 \%)$ was again exclusive to the forest interior and appeared in several samples, but only during summer males and females occurred together (Fig. 18). Testudinaria quadripunctata was a singleton in the grassland edge. LEVI (2005) cites this species as well represented in varied environments and vegetation strata, but as their webs are nocturnal, this might explain its low representation here.

The results show that the Araneidae fauna of Rio Grande do Sul State is becoming well known taxonomically, however, more work focusing on ecological aspects are necessary. Our expectations about different araneid spider abundance and richness on rivers were confirmed, and the biological edge hypothesis, considering the distinct nature of edges, evaluated here, was also confirmed. We need to better understand the life histories of the spiders from this family in different ecosystems and their habitats in southern Brazil. We hope the increasing amount of information on Neotropical spiders being produced will allow us nevertheless to paint a picture of the relationships of araneid spiders and riparian forests, fostering the understanding of the ecosystems they live in as well. They can be invaluable for conservation efforts, given their important ecosystem function and even its public appeal.

Acknowledgements. To José Vanderlei Feltrim for allowing the study to occur in his area in the Maquiné river and for the information provided on the area. To Maria A. L. Marques, Erica H. Buckup and the direction of Museu de Ciências Naturais (MCN) by permitting the first author to develop part of this work in its facilities. This study was supported by Conselho Nacional de Desenvolvimento Científico e Tecnológico (CNPq 140586/2007-5 for E.N.L. Rodrigues).

\section{REFERENCES}

Baldissera, R.; Ganade, G. \& Fontoura, S. B. 2004. Web spider community response along an edge between pasture and Araucaria Forest. Biological Conservation 118:403-409.

Baldissera, R.; Ganade, G; Brescovit, A. D. \& Hartz, S. M. 2008. Landscape mosaic of Araucaria forest and forest monoculture influencing understory spider assemblages in southern Brazil. Austral Ecology 33:45-54.

Benati, K. R.; Souza-Alves, J. P.; Silva, E. A.; Peres, M. C. L. \& Coutinho, E. O. 2005. Aspectos comparativos das comunidades de aranhas (Araneae) em dois remanescentes de Mata Atlântica da Bahia, Brasil. Biota Neotropica 5(1a). Available at $<\mathrm{http}$ ://www.biotaneotropica. org.br/v5n1a/pt/abstract?inventory+BN005051a2005> .

Bonaldo, A. B.; Marques, M. A. L.; Pinto-Da-Rocha, R. \& Gardner, T. 2007. Species richness and community structure of arboreal spider assemblages in fragments of three vegetacional types at Banhado Grande wet plain, Gravataí river, Rio Grande do Sul, Brazil. Iheringia, Série Zoologia 97(2):143-151.
Buckup, E. H.; MArques, M. A. L.; Rodrigues, E. N. L. \& Ott, R. 2010. Lista das espécies de aranhas (Arachnida, Araneae) do estado do Rio Grande do Sul, Brasil. Iheringia, Série Zoologia 100(4):483-518.

Clarke, K. R. \& Warwick, R. M. 1994. Change in Marine Communities. United Kingdom, National Research Concil, 144p.

Coddington, J. A.; Agnarsson, I; Miller, J. A.; Kuntner, M. \& Hormiga, G. 2009. Undersampling bias: the null hypothesis for singleton species in tropical arthropod surveys. Journal of Animal Ecology 78:573-584.

Colwell, R.K. 2005. EstimateS: statistical estimation of species richness and shared species from samples. Version 7.5.1. University of Connecticut, USA. Available at $<$ http://viceroy.eeb.uconn.edu/ EstimateS>.

Conservation International do Brasil, Fundação SOS Mata Atlântica, Fundação Biodiversitas, Instituto de Pesquisas Ecológicas, Secretaria do Meio Ambiente do Estado de São Paulo \& Semad/ Instituto Estadual de Florestas, MG. 2000. Avaliações e ações prioritárias para a conservação da biodiversidade da Mata Atlântica e Campos Sulinos. Brasília, Ministério do Meio Ambiente. 40p.

DANiEL, A. 1991. Estudo fitossociológico arbóreo/arbustivo da mata ripária da Bacia Hidrográfica do rio dos Sinos, RS. Pesquisas, Botânica 42:1-199.

Foelix, R. F. 1996. Biology of spiders. New York, Oxford University Press. 336p.

Hammer, O. \& Harper, D. A. T. 2009. Past: Paleontological Statistics. Version 1.97. Available at $<$ http://folk.uio.no/ohammer/past $>$.

Harper K. A.; Mascarua-Lopez, L.; Macdonald, S. E. \& Drapeau, P. 2007. Interaction of edge influence from multiple edges: examples from narrow corridors. Plant Ecology 192:71-84.

IndRusiaK, L. F. \& Buss, R. G. 2003. Lista de espécies de aranhas da região central do Rio Grande do Sul - Família Araneidae. Ciência e Natura 25:51-60.

INDRUSIAK, L. F. \& KotZIAN, C. B. 1998. Inventário das aranhas arborícolas de três regiões de Santa Maria, RS, Brasil. Ciência e Natura 20:187214.

Laeser, S. R.; BaXter, C. V. \& Fausch, K. D. 2005. Riparian vegetation loss, stream channelization, and web-weaving spiders in northen Japan. Ecological Research 20:46-651.

Levi, H. W. 1991. The Neotropical and Mexican species of the orb-weaver genera Araneus, Dubiepeira and Aculepeira (Araneae: Araneidae). Bulletin of the Museum of the Comparative Zoology 152(4):167315 .

1995. The Neotropical orb-weaver genus Metazygia (Araneae: Araneidae). Bulletin of the Museum of the Comparative Zoology 154(2):63-151.

1999.The Neotropical and Mexican orb weavers of the genera Cyclosa and Allocyclosa (Araneae: Araneidae). Bulletin of the Museum of the Comparative Zoology 155(7):299-379.

2002. Keys of the genera of araneid orbweavers (Araneae, Araneidae) of the Americas. Journal of Arachnology 30(3):527-562. . 2005. The spider genera Heterognatha, Testudinaria and Ursa in South America (Araneae: Araneoidea). Bulletin of the British Arachnological Society 13(6): 185-198.

MurCiA, C. 1995. Edge effect in fragmented forests: implications for conservation. Trends Ecology Evolution 10:58-62.

Podgaiski, L. R.; Ott, R.; Rodrigues, E. N. L.; Buckup, E. H. \& Marques, M. A. L. 2007. Araneofauna (Arachnida, Araneae) do Parque Estadual do Turvo, Rio Grande do Sul, Brasil. Biota Neotropica 7(n2). Available at $<\mathrm{http}: / /$ www.biotaneotropica.org.br/v7n2/pt/ab stract?inventory+bn01107022007>.

Raizer, J.; Japyassú, H. F.; Indicatti, R. P. \& Brescovit, A. D. 2005. Comunidade de aranhas (Arachnida, Araneae) do pantanal norte (Mato Grosso, Brasil) e sua similaridade com a araneofauna amazônica. Biota Neotropica 5(1a). Available at $<\mathrm{http}: / /$ www.biotaneotropica. org.br/v5n1a/pt/abstract?inventory+ BN009051a2005>.

Rodrigues, E. N. L. 2005 Fauna araneológica (Arachnida, Araneae) arborícola de duas áreas em uma mata de restinga no sul do Brasil. Acta Biologica Leopoldensia 27(1):73-92.

Rodrigues, E. N. L. \& MendonçA, JR., M. S. 2012. Spider guilds in the tree-shrub strata of riparian forests in southern Brazil. Journal of Arachnology 40:39-47. 
Rodrigues, E. N. L.; MendonçA, Jr., M. S. \& Costa-Schmidt, L. E. 2014. Spider diversity responds strongly to edge effects but weakly to vegetation structure in riparian forests of Southern Brazil. ArthropodPlant Interactions 8:123-133.

Silva, E. L. C. \& AraúJo, A. M. 2005. Distribuição e diversidade das espécies de aranhas (Araneae) coletadas na região de Tainhas e Terra de Areia, Rio Grande do Sul, Brasil. Revista Brasileira de Zoociências 7(2):285-296.

Toti, D. S.; Coyle, F. A. \& Miller, J. A. 2000. A structured inventory of Appalachian Grass Bald and Heath Bald spider assemblages and a test of species richness estimator performance. Journal of Arachnology 28:329-345.
Wirth, R.; Meyer, S. T.; Leal, I. R. \& Tabarelli, M. 2008. Plant Herbivore Interactions at the Forest Edge. In: Lüttge, U.; Beyschlag, W. \& Murata, J. eds. Progress in Botany 69. Berlin, Springer-Verlag. 479p. World Spider Catalog. 2015. World Spider Catalog. Natural History Museum Bern. Available at $<$ http://wsc.nmbe.ch $>$. Accessed on January, 2015. 